\title{
Factors Influencing Implementation Of Shared Medical Decision Making In Patients With Cancer
}

This article was published in the following Dove Press journal:

Patient Preference and Adherence

\section{Huei-Lan Chang' \\ Fang-Shan $\mathrm{Li}^{1}$ \\ Chiou-Fen $\operatorname{Lin}^{2,3}$}

'Nursing Department, National Taiwan University Hospital Hsinchu Branch, Hsinchu City, Taiwan; ${ }^{2}$ College of Nursing, School of Gerontology Health Management, Taipei Medical University, Taipei, Taiwan; ${ }^{3}$ Department of Nursing, Shuang Ho Hospital, Taipei Medical University, Taipei, Taiwan
Correspondence: Chiou-Fen Lin College of Nursing, School of Gerontology Health Management, Taipei Medical University, 250 Wu-Hsing Street, Taipei City II0, Taiwan

Tel +88622736 I66I Ext. 634I

Email cflin@tmu.edu.tw
Purpose: Shared decision making promotes patient participation in medical decisions. This study aims to explore the decision-making situation and influencing factors in patients with cancer.

Patients and methods: A cross-sectional descriptive study was conducted for patient with cancers in regional teaching hospitals in northern Taiwan using short-form Mandarin Health Literacy Scale (s-MHLS) and Shared Decision Making Questionnaire (SDM-Q-9), with total 120 cases collected from January 15 to April 30, 2018.

Results: Overall health literacy in patients with cancer is $86.52 \%$, and degree of shared decision making is $89.63 \%$; higher education level indicated better health literacy $(\mathrm{p}<0.001)$; health literacy is significantly correlated with Shared decision making $(r=0.258, \mathrm{p}=0.004)$. Increasing education level by one grade elevated health literacy by 0.623 . Expanding health knowledge by one source increased health literacy by 0.307 points, one point increase in health literacy enhanced shared decision making by 0.128 points. Using path analysis, we found education level affects health literacy, which in turn influences shared decision making.

Conclusion: Improving health literacy is indispensable to promote patient participation in shared decision making in the highly professional medical field. Education level directly affects health literacy; therefore, in the future, providing disease-matching health education is crucial for patients with lower education levels to enhance their health literacy. Health literacy directly affects shared decision making; therefore, more active assistance in achieving patient health literacy is crucial to implement shared decision making.

Keywords: health literacy, shared decision making, patient-physician communication, patients with cancer

\section{Introduction}

Taiwan passed the first Patient Autonomy Act in Asia through the Legislative Yuan in 2015. The law aims to ensure that patients have the right to know, choose and refuse medical care, and in addition to "being informed", patients can "choose" their medical options; ${ }^{1}$ The basic tenants of the legislation is to respect the patient's autonomy in medical decision making, to protect the patient's hospice rights, to promote the harmony in the doctor-patient relationship, and all the above can be achieved via shared decision making (SDM). ${ }^{2}$ With the increase of people's willingness to participate, previous one-way communication, i.e., patients were only informed or taught by medical professionals for how to participate, has gradually failed to meet their expectations. $^{3}$ On November 21, 2016, the public participation section of the Joint Commission of Taiwan (JCT) website remarked on the origin of the SDM. The SDM 
resource sharing platform was established, not only to serve as a communication platform to assist in decision-making for medical institutions but also to reduce waste of resources. ${ }^{4}$

With the development of science and technology, it is much easier for the consumers to obtain medical information. Currently, medical information can be accessible and understood easily, thus reduces the inequality between doctor and patient, however, will induce more medical dispute. Indeed, poor medical communication is the main cause of their tight relationship. ${ }^{5}$ Shared decision allows patients and medical teams to review evidence-based data and treatment options before making medical decisions so that patients can make medical decisions according to their willingness. ${ }^{6}$ Information from evidence-based medicine and the patient preferences are incorporated for the decision-making discussions. At the same time, patient's health literacy (HL), concept of risk, and doctor-patient relationship are improved, whereas conflicts in decisionmaking, patient's feeling of uninformed, and the possibility of patient's exposure to inappropriate inspection and treatment are reduced. ${ }^{7}$ The exercise of autonomy by patients should be regarded as the right instead of the obligation. For patients, autonomy should be their rights rather than obligations. Different from Western cultures, Taiwan is more patriarchy, therefore, medical personnel must pay more attention to distinguish patient's values, preferences and provide patient treatment efficacy with evidence in nowadays practices. ${ }^{8,9}$ In recent years, more and more international research has advocated SDM as an ideal model for medical decision-making. ${ }^{8}$

However, there are still few medical professionals who try to promote patient participation via SDM or adjust their care according to the patient's willingness during the process of clinical medical care today. ${ }^{10,11}$ Albeit the popularity of compulsory education in Taiwan, and that healthcare system attaches more importance to the needs and necessity of providing people with a variety of health information and choices, there are still minimal evidencebased research to date on the current status of the patient HL, i.e., the patient's ability to inquire, read, and understanding of medical information, and whether the experience of interaction with medical professionals still affects their communication and healthcare.

Although the medical policy committee started to drive the concept of SDM in 2016, Taiwan has just started to promote it recently. Not too many related studies have been performed. Whether the patient and medical care provider have applied this concept of SDM in health communication needs to be further analyzed. In addition, culture difference between the domestic and foreign medical environments highlights the importance of understanding current status of local SDM practice and its influence factors, so as to narrow the communication gap and to truly implement patient participation in the SDM. The highly diverse treatment and medication for patient with cancers prompted us to investigate the participation in medical SDM and related influence factors in patients with cancer.

\section{Patients And Methods Design}

A cross-sectional descriptive study design was applied to evaluate the progress in achieving patients' $\mathrm{HL}$ and the implementation of SDM. This study is performed in a teaching hospital with approximately 800 beds in northern Taiwan. Patients with various cancer diagnoses and under surgery, medication, and treatments in line with key elements in SDM are recruited. The researcher collected clinical data personally from a total of 120 patients with cancer. Data were collected from January 15 to April 30, 2018.

\section{Inclusion And Exclusion Criteria}

Patients with cancer, over the age of 20 , able to communicate in Mandarin, Hokenese, or Hakka, and willing to provide written informed consent, and meet the key elements in SDM were included in this study. Patients were excluded from the study if they are not capable of making decisions, family members tend to keep conditions a secret, not conscious, not willing to fill out the questionnaire cooperatively.

\section{Evaluation Measures Health Literacy}

The "short-form Mandarin Health Literacy Scale" (sMHLS) containing two sets of questions, i.e., "outpatient dialogue" and "medication information" was applied. Of the total 11 questions, 8 are text reading ability tests and 3 are digital ability tests. Simulation of the communication between the patient and medical personnel is incorporated in the design of questionnaire to assess the subject's understanding of the conversation and is a HL assessment tool suitable for the Chinese language population in Taiwan. The questionnaire is aimed to evaluate the ability to read, understand, and apply health information of the subject; therefore, the participant has to complete the questionnaire 
on his own and other people are not allowed to provide opinions or clues, nor do they explain the meaning of the questions to the participants. Right answer to each question contributes to 1 point, and the highest and lowest score are 11 and 0 points, respectively.

\section{Patient's Own Assessment About The Degree Of SDM}

Adopt the Shared Decision Making Questionnaire, SDMQ, by the German scholar Simon et al in 2006, who optimize the questionnaire based on the SDM model developed by Charles, Gafni and Whelan $(1997)^{8}$ through clearer definition of the concept and self-assessment by the patient. There are a total of 11 questions, after the simplification by Kriston et al (2009) $)^{12}$ to the SDM-Q-9 version; the number of questions is reduced to 9 and the Cronbach's $\alpha$ value is 0.94 . The way to answering the questions is based on the $0-5$ six-point Likert scale; 0 means "completely disagree", 1 means "mostly disagree", 2 means "slightly disagree", 3 means "slightly agree", 4 means "mostly agree", and 5 means "completely agree" that the description matches the real experience. The total score obtained after the summation was divided with 9 and then multiplied by 20 to get a score of percentage from 0 to 100 . The higher the score, the higher the level patient assessed the degree of SDM with the medical team.

\section{Statistical Analysis}

At the time of collecting the questionnaires, the researcher reviewed its integrity and concealed the coding of the questionnaire. SPSS 20.0 Chinese version and R3.5 software were used according to the research aim and targets of this study. Significant level was set as $\mathrm{p}<0.05$.

\section{Results}

\section{Demographic Variable}

The age ranged from 24 to 94 years old, with an average of 54.5, SD $=12.0 .50-59$ years of age, accounts for $35.8 \%$, represents the largest population of the participants. There are 60 males and 60 females, each accounting for $50.0 \%$. For the education level, college represents the largest proportion, which accounts for $35.0 \%$. Most of the participants are married, accounting for $74.2 \%$. For the occupation, unemployed and retired represent the most, accounting for $44.2 \%$. For the religion, the largest proportion is Buddhism, accounting for $40.0 \%$. For the habits of reading newspapers, not reading represents the most, accounting for $54.2 \%$. For the sources of health knowledge, one type is the most common, accounting for $43.3 \%$. For the cancer category, chest cancer is the largest population, accounting for $38.3 \%$. For the main caregivers, family member is the most common, accounting for $82.5 \%$. The details are summarized in Table 1 .

\section{Patient With Cancer HL}

The mean score was $9.52(\mathrm{SD}=1.68)$ out of 11 points, and the overall correct rate was $86.52 \%$. The details are summarized in Table 2.

\section{Degree Of Patient With Cancer Participation In SDM}

The average score of self-assessment of participation in SDM with medical team is $4.48(\mathrm{SD}=0.76)$ out of 5 points, and the percentage is $89.63 \%$ after conversion, indicating that most patients were invited by the medical care team for SDM, at the same time, relevant information on treatment were also fully explained and communicated. It revealed the worst feeling of the patient with cancers in "the physician tries to understand from the conversation that how do I participate in the SDM in my mind." Details are summarized in Table 3.

\section{Differences Between Demographic Variables Versus The HL Or Feeling Of SDM \\ Differences Between Demographic Variables And Patient HL}

The analysis revealed significant differences in age, gender, education level, occupation, and the source of health knowledge. Scheffe post hoc test was carried out for those with significant between-group differences, results indicated HL was better achieved in the age group of $\leqq 49$ years old and 50-59 years old, as compared to the group $\geqq 60$ years old; for the education level, HL was less achieved in the junior high school group (including) when compared to senior high school, college and graduate school; For the source health knowledge source, HL was less achieved in the group of 0 as compared to either 2 of TV, newspaper, internet, books, and broadcasting. Table 4 illustrates the details.

\section{Differences Between Demographic Variables And Patients' Feeling Of SDM}

The results revealed no statistically significant difference between all demographic variables and degree of patient with cancer participation in the decision-making process. 
Table I Distribution Of The Demographic Variables Of The Participants $(\mathrm{N}=120)$

\begin{tabular}{|c|c|c|c|c|}
\hline Variable & Category & Number & $\%$ & $\begin{array}{l}\text { Mean } \\
\pm S D\end{array}$ \\
\hline Age & $\begin{array}{l}\leqq 49 \text { years old } \\
50-59 \text { years old } \\
\geqq 60 \text { years old }\end{array}$ & $\begin{array}{l}120 \\
36 \\
43 \\
41\end{array}$ & $\begin{array}{l}30.0 \\
35.8 \\
34.2\end{array}$ & $54.5 \pm 12.0$ \\
\hline Gender & $\begin{array}{l}\text { Male } \\
\text { Female }\end{array}$ & $\begin{array}{l}60 \\
60\end{array}$ & $\begin{array}{l}50.0 \\
50.0\end{array}$ & \\
\hline Education & $\begin{array}{l}\text { Below (include) } \\
\text { junior high } \\
\text { school } \\
\text { Senior high } \\
\text { school } \\
\text { College } \\
\text { Above (include) } \\
\text { graduate school }\end{array}$ & $\begin{array}{l}34 \\
37 \\
\\
42 \\
7\end{array}$ & $\begin{array}{l}28.3 \\
30.8 \\
35.0 \\
5.8\end{array}$ & \\
\hline Marital status & $\begin{array}{l}\text { Single } \\
\text { Married } \\
\text { Divorced }\end{array}$ & $\begin{array}{l}18 \\
89 \\
13\end{array}$ & $\begin{array}{l}15.0 \\
74.2 \\
10.8\end{array}$ & \\
\hline Occupation & $\begin{array}{l}\text { None/retired } \\
\text { Service industry } \\
\text { Worker } \\
\text { Public servant } \\
\text { Homemaker }\end{array}$ & $\begin{array}{l}53 \\
15 \\
26 \\
4 \\
22\end{array}$ & $\begin{array}{l}44.2 \\
12.5 \\
21.7 \\
3.3 \\
18.3\end{array}$ & \\
\hline Religion & $\begin{array}{l}\text { None } \\
\text { Buddhism } \\
\text { Christianity } \\
\text { Catholicism } \\
\text { Taoism } \\
\text { Other }\end{array}$ & $\begin{array}{l}35 \\
48 \\
5 \\
4 \\
23 \\
5\end{array}$ & $\begin{array}{l}29.2 \\
40.0 \\
4.2 \\
3.3 \\
19.2 \\
4.2\end{array}$ & \\
\hline $\begin{array}{l}\text { Habits of } \\
\text { reading } \\
\text { newspapers }\end{array}$ & $\begin{array}{l}\text { No } \\
\text { I-3 days/week } \\
\text { 4-7 days/week }\end{array}$ & $\begin{array}{l}65 \\
32 \\
23\end{array}$ & $\begin{array}{l}54.2 \\
26.7 \\
19.2\end{array}$ & \\
\hline $\begin{array}{l}\text { Sources of } \\
\text { health } \\
\text { knowledge } \\
\text { (type) }\end{array}$ & $\begin{array}{l}\text { No } \\
\text { I Type } \\
2 \text { Types } \\
3 \text { Types } \\
\text { 4-5 Types }\end{array}$ & $\begin{array}{l}3 \\
52 \\
24 \\
24 \\
17\end{array}$ & $\begin{array}{l}2.5 \\
43.3 \\
20.0 \\
20.0 \\
14.2\end{array}$ & \\
\hline Main care giver & $\begin{array}{l}\text { No } \\
\text { Yes }\end{array}$ & $\begin{array}{l}21 \\
99\end{array}$ & $\begin{array}{l}17.5 \\
82.5\end{array}$ & \\
\hline Cancer category & $\begin{array}{l}\text { Head/Neck } \\
\text { Chest } \\
\text { Abdomen } \\
\text { Gynecologic/ } \\
\text { Hematologic/ } \\
\text { Other }\end{array}$ & $\begin{array}{l}27 \\
46 \\
41 \\
6\end{array}$ & $\begin{array}{l}22.5 \\
38.3 \\
34.2 \\
5.0\end{array}$ & \\
\hline
\end{tabular}

Table 2 Descriptive Analysis Results Of Health Literacy In Patients With Cancer $(\mathrm{N}=120)$

\begin{tabular}{|c|l|l|l|l|l|}
\hline \multirow{2}{*}{ Item } & \multicolumn{2}{l|}{ Correct } & Ranking & Mean & SD \\
\cline { 2 - 4 } & Number & $\%$ & & & \\
\hline $\begin{array}{l}\text { Outpatient } \\
\text { dialogue }\end{array}$ & & & & 3.66 & 0.67 \\
Q1 & 105 & 87.5 & 7 & & \\
Q2 & 111 & 92.5 & 3 & & \\
Q3 & 115 & 95.8 & 2 & & \\
Q4 & 108 & 90.0 & 6 & & \\
\hline Medication & & & & 5.86 & 1.25 \\
information & & & & & \\
Q5 & 117 & 97.5 & 1 & & \\
Q6 & 109 & 90.8 & 4 & & \\
Q7 & 95 & 79.2 & 9 & & \\
Q8 & 109 & 90.8 & 5 & & \\
Q9 & 98 & 81.7 & 8 & & \\
Q10 & 83 & 69.2 & 11 & & \\
Q11 & 92 & 76.7 & 10 & & \\
\hline Overall & & 86.52 & & 9.52 & 1.68 \\
\hline
\end{tabular}

Notes: QI: Doctor! My right big toe started to hurt __ from four or five days ago, and it became more and more painful without getting better. Q2: Paronychia is a kind of tissue inflammation, I will prescribe some _ to you to reduce redness and pain. Q3: Do you have diabetes history? Please __ and carry out blood test with this checkup form at the next visit. Q4: Don't wear _ shoes after going home, keep your feet dry and breathe. If not continue to get worse, come back to the clinic 5 days later. Q5: What is the name of the patient taking this medicine? Q6: When should the patient use the drug? Q7: If taking it before this breakfast, it is best to take it _ next time. Q8: How much should take for this drug each time? Q9: The doctor prescribed a total of ___ days of drug dose this time. Q10: Taking this medicine may have side effects associated with hypoglycemia, such as ___ symptoms. QI I: Patient taking this medicine should avoid driving or operating heavy machinery before being stabilized.

The variables in the SDM-Q-9 were further divided. Variables 1, 2, and 3 were categorized as Choice talk in the SDM process, variables $4,5,6$, and 7 were categorized as Option talk in the SDM process, and variables 1, 2, and 3 were grouped as Decision talk in the SDM process. Results indicated that significant difference $(p<0.05)$ in marital status and degree of Option talk; Scheffe post-hoc analysis showed that degree of Option talk was higher in married group as compared to the divorced group, indicating the impact of family on the patient's option in the Chinese community. The results are detailed in Table 5.

\section{Correlation Analysis Between Demographic Variables And HL And Degree Of Feeling About SDM}

Through the Pearson correlation coefficient analysis, results showed that age (correlation coefficient $r=-0.321, p<0.001$ ), education level (correlation coeffi- 
Table 3 Feeling Of The Patient With Cancers During Implementation Of Shared Decision Making (SDM) (N=120)

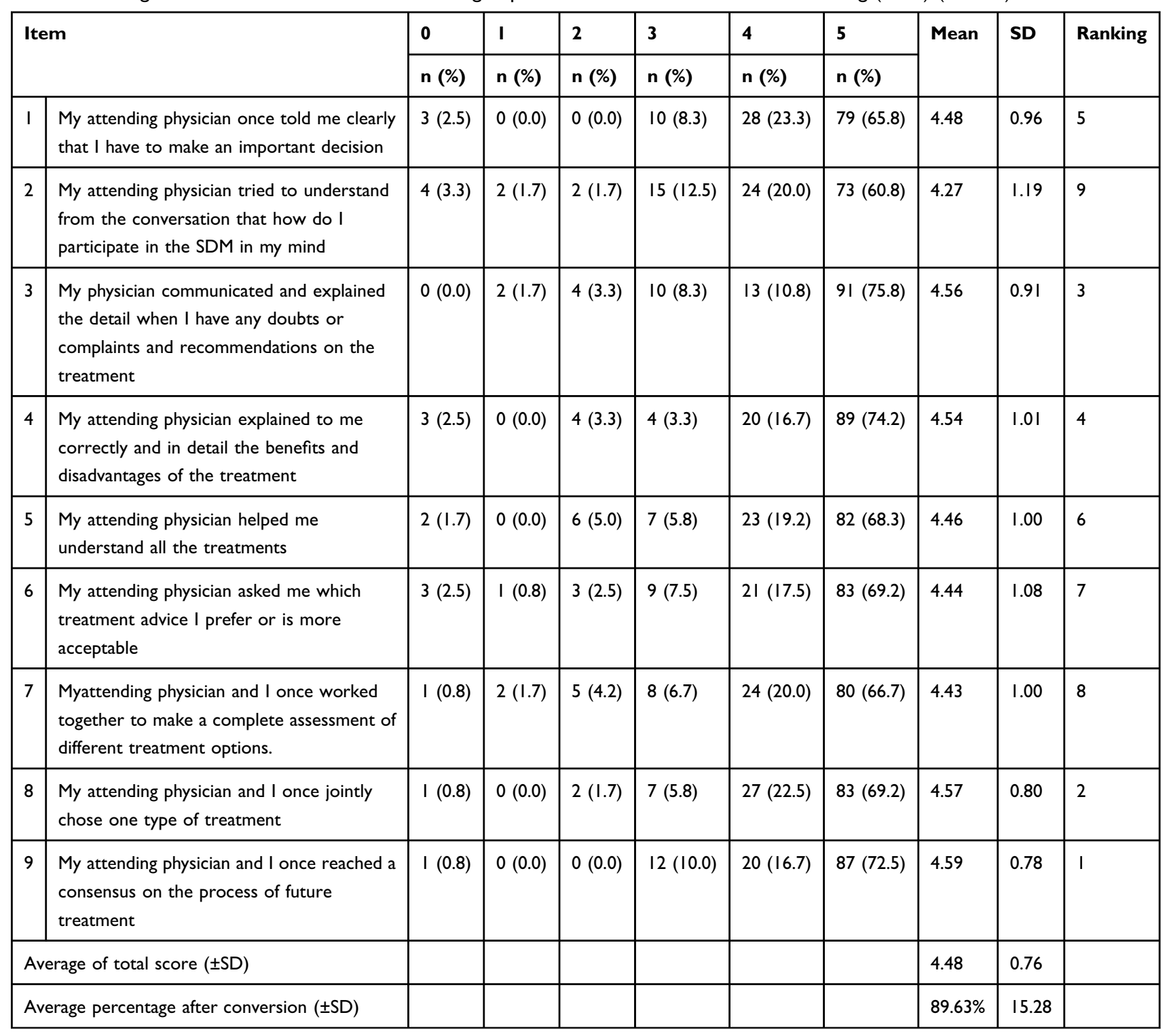

cient $\mathrm{r}=0.480, \mathrm{p}<0.001)$, and the source of health knowledge (correlation coefficient $\mathrm{r}=0.320, \mathrm{p}<0.001$ ) were significantly correlated with HL. In addition, statistically significant correlation was found between the HL and the degree of feeling in the SDM process (correlation coefficient $\mathrm{r}=0.258, \mathrm{p}=0.004)$. The details are summarized in Table 6.

\section{Important Factors Predicting HL And Feeling Of The Extent Of SDM Important Factors Predicting HL Of Patient With Cancers}

Multiple linear regression was applied to analyze the important predictors affecting patient with cancer's HL.
The resulting regression line from Table 7 is: healthy literacy $=8.032+0.623 \mathrm{x}$ education level $+0.307 \mathrm{x}$ source of health knowledge (type), i.e., in patients with cancer, for each increase in the educational level by one grade, the HL can be improved by 0.623 points; for each increase in the source (type) of health knowledge, the HL will be improved by 0.307 points.

\section{Important Factors Predicting The Extent Of SDM In} Patients With Cancer

The resulting multiple linear regression line obtained from Table 8 is: $\mathrm{SDM}=3.112+0.128 \mathrm{x}$ health literacy, i.e., in patients with cancer, for every 1 point increase in the average score of $\mathrm{HL}$, the extent of SDM is increased by 0.128 points. 
Table 4 Intergroup Differences Between Demographic Variables And Health Literacy In Patients With Cancer

\begin{tabular}{|c|c|c|c|c|c|}
\hline Variable/Category & Number & $\begin{array}{l}\text { Health Literacy } \\
\text { Mean士SD }\end{array}$ & $\begin{array}{l}\text { t-Value/F- } \\
\text { Value }\end{array}$ & P-Value & Scheffe Post-Hoc Analysis \\
\hline $\begin{array}{l}\text { Age } \\
\qquad 49 \text { years old } \\
50-59 \text { years old } \\
\geqq 60 \text { years old }\end{array}$ & $\begin{array}{l}36 \\
43 \\
41\end{array}$ & $\begin{array}{l}10.08 \pm 0.996 \\
9.74 \pm 1.43 \\
8.78 \pm 2.10\end{array}$ & 7.069 & $0.001 *$ & $\begin{array}{l}49 \text { years old }>60 \text { years old; } \\
50-59 \text { years old }>60 \text { years old }\end{array}$ \\
\hline $\begin{array}{l}\text { Gender } \\
\text { Male } \\
\text { Female }\end{array}$ & $\begin{array}{l}60 \\
60\end{array}$ & $\begin{array}{l}9.15 \pm 1.70 \\
9.88 \pm 1.58\end{array}$ & -2.447 & $0.016^{*}$ & \\
\hline $\begin{array}{l}\text { Education level } \\
\text { Below (include) junior high school } \\
\text { Senior high school } \\
\text { College } \\
\text { Above (include) graduate school }\end{array}$ & $\begin{array}{l}34 \\
37 \\
42 \\
7\end{array}$ & $\begin{array}{l}8.29 \pm 2.08 \\
9.57 \pm 1.50 \\
10.31 \pm 0.75 \\
10.43 \pm 0.79\end{array}$ & 12.816 & $<0.001 * * *$ & $\begin{array}{l}\text { Below junior high school < senior high school, college, } \\
\text { above graduate school }\end{array}$ \\
\hline $\begin{array}{l}\text { Marital status } \\
\text { Single } \\
\text { Married } \\
\text { Divorced }\end{array}$ & $\begin{array}{l}18 \\
89 \\
13\end{array}$ & $\begin{array}{l}9.56 \pm 1.69 \\
9.45 \pm 1.72 \\
9.92 \pm 1.38\end{array}$ & 0.455 & 0.636 & \\
\hline $\begin{array}{l}\text { Occupation } \\
\text { No/retired } \\
\text { Service industry } \\
\text { Worker } \\
\text { Public servant } \\
\text { Homemaker }\end{array}$ & $\begin{array}{l}53 \\
15 \\
26 \\
4 \\
22\end{array}$ & $\begin{array}{l}9.00 \pm 1.93 \\
10.27 \pm 0.70 \\
9.92 \pm 1.35 \\
10.25 \pm 0.96 \\
9.64 \pm 1.62\end{array}$ & 2.770 & $0.031^{*}$ & \\
\hline $\begin{array}{l}\text { Religion } \\
\text { None } \\
\text { Buddhism } \\
\text { Christianity } \\
\text { Catholicism } \\
\text { Taoism } \\
\text { Other }\end{array}$ & $\begin{array}{l}35 \\
48 \\
5 \\
4 \\
23 \\
5\end{array}$ & $\begin{array}{l}9.71 \pm 1.64 \\
9.18 \pm 1.67 \\
10.20 \pm 1.10 \\
10.75 \pm 0.50 \\
9.39 \pm 1.92 \\
10.20 \pm 1.30\end{array}$ & 1.275 & 0.280 & \\
\hline $\begin{array}{l}\text { Habit of reading newspaper } \\
\text { No } \\
\text { Days/week I-3 } \\
\text { Days/week 4-7 }\end{array}$ & $\begin{array}{l}65 \\
32 \\
23\end{array}$ & $\begin{array}{l}9.40 \pm 1.82 \\
9.84 \pm 1.46 \\
9.39 \pm 1.53\end{array}$ & 0.830 & 0.439 & \\
\hline $\begin{array}{l}\text { Source of health knowledge } \\
\text { (type) } \\
\text { None } \\
\text { I Type } \\
2 \text { Types } \\
\text { 3 Types } \\
\text { 4-5 Types }\end{array}$ & $\begin{array}{l}3 \\
52 \\
24 \\
24 \\
17\end{array}$ & $\begin{array}{l}8.33 \pm 1.53 \\
8.90 \pm 1.83 \\
9.95 \pm 1.49 \\
10.17 \pm 0.96 \\
10.05 \pm 1.64\end{array}$ & 4.311 & $0.003^{* *}$ & None $<2$ types \\
\hline $\begin{array}{l}\text { Main caregiver } \\
\text { None } \\
\text { Family/friend/caretaker }\end{array}$ & $\begin{array}{l}21 \\
99\end{array}$ & $\begin{array}{l}8.62 \pm 1.86 \\
9.71 \pm 1.58\end{array}$ & -2.779 & 0.250 & \\
\hline $\begin{array}{l}\text { Cancer category } \\
\text { Head/Neck } \\
\text { Chest } \\
\text { Abdomen } \\
\text { Gynecologic/Hematologic/Other }\end{array}$ & $\begin{array}{l}27 \\
46 \\
41 \\
6\end{array}$ & $\begin{array}{l}9.81 \pm 1.38 \\
9.63 \pm 1.78 \\
9.39 \pm 1.73 \\
8.17 \pm 1.17\end{array}$ & 1.766 & 0.158 & \\
\hline
\end{tabular}

Notes: $* \mathrm{P}<0.05, * * \mathrm{P}<0.01, * * * \mathrm{P}<0.001$. 
Table 5 Inter-Group Differences Between Demographic Variables And Feeling Of The Patient With Cancers During Implementation Of SDM-Option Talk

\begin{tabular}{|c|c|c|c|c|c|}
\hline \multirow[t]{2}{*}{ Variable/ltem } & \multirow[t]{2}{*}{ Number } & Option Talk & \multirow[t]{2}{*}{$\mathrm{t}$-Value/F-Value } & \multirow[t]{2}{*}{ P-Value } & \multirow[t]{2}{*}{ Scheffe Post-Hoc Analysis } \\
\hline & & Mean士SD & & & \\
\hline Age & & & 0.459 & 0.633 & \\
\hline$\leqq 49$ years old & 36 & $4.41 \pm 1.13$ & & & \\
\hline $50-59$ years old & 43 & $4.58 \pm 0.73$ & & & \\
\hline$\geqq 60$ years old & 41 & $4.4 I \pm 0.87$ & & & \\
\hline Gender & & & -0.125 & 0.901 & \\
\hline Male & 60 & $4.46 \pm 1.00$ & & & \\
\hline Female & 60 & $4.48 \pm 0.81$ & & & \\
\hline Education level & & & 0.976 & 0.407 & \\
\hline Below (include) junior high school & 34 & $4.32 \pm 1.01$ & & & \\
\hline Senior high school & 37 & $4.44 \pm 0.91$ & & & \\
\hline College & 42 & $4.65 \pm 0.78$ & & & \\
\hline Above (include) graduate school & 7 & $4.29 \pm 1.10$ & & & \\
\hline Marital status & & & 4.060 & $0.020^{*}$ & Married > divorced \\
\hline Single & 18 & $4.32 \pm 1.23$ & & & \\
\hline Married & 89 & $4.59 \pm 0.68$ & & & \\
\hline Divorced & 13 & $3.87 \pm 1.46$ & & & \\
\hline Occupation & & & 0.297 & 0.879 & \\
\hline No/retired & 53 & $4.45 \pm 0.74$ & & & \\
\hline Service industry & 15 & $4.27 \pm 1.47$ & & & \\
\hline Worker & 26 & $4.53 \pm 0.99$ & & & \\
\hline Public servant & 4 & $4.69 \pm 0.24$ & & & \\
\hline Homemaker & 22 & $4.53 \pm 0.81$ & & & \\
\hline Religion & & & 0.292 & 0.916 & \\
\hline None & 35 & $4.46 \pm 0.98$ & & & \\
\hline Buddhism & 48 & $4.51 \pm 0.79$ & & & \\
\hline Christianity & 5 & $4.40 \pm 0.72$ & & & \\
\hline Catholicism & 4 & $4.56 \pm 0.43$ & & & \\
\hline Taoism & 23 & $4.50 \pm 1.11$ & & & \\
\hline Other & 5 & $4.00 \pm 1.17$ & & & \\
\hline Habit of reading newspaper & & & 0.326 & 0.723 & \\
\hline No & 65 & $4.44 \pm 0.93$ & & & \\
\hline Days/week I-3 & 32 & $4.58 \pm 0.74$ & & & \\
\hline Days/week 4-7 & 23 & $4.40 \pm 1.07$ & & & \\
\hline Source of health knowledge (type) & & & 1.255 & 0.292 & \\
\hline None & 3 & $5.00 \pm 0.00$ & & & \\
\hline I Type & 52 & $4.28 \pm 1.17$ & & & \\
\hline 2 Types & 24 & $4.48 \pm 0.84$ & & & \\
\hline 3 Types & 24 & $4.67 \pm 0.45$ & & & \\
\hline 4-5 Types & 17 & $4.65 \pm 0.50$ & & & \\
\hline Main caregiver & & & -0.883 & 0.379 & \\
\hline No & 21 & $4.31 \pm 0.97$ & & & \\
\hline Yes & 99 & $4.50 \pm 0.90$ & & & \\
\hline Cancer category & & & 0.942 & 0.423 & \\
\hline Head/Neck & 27 & $4.44 \pm 1.08$ & & & \\
\hline Chest & 46 & $4.33 \pm 0.90$ & & & \\
\hline Abdomen & 41 & $4.60 \pm 0.86$ & & & \\
\hline Gynecologic/Hematologic/Other & 6 & $4.79 \pm 0.19$ & & & \\
\hline
\end{tabular}

Notes: $* P<0.05$. 
Table 6 Correlation Test Of Demographic Variables And Health Literacy And Feeling During Implementation Of SDM (Pearson Correlation Coefficient)

\begin{tabular}{|l|l|l|l|l|}
\hline \multirow{2}{*}{ Variable } & \multicolumn{2}{|l|}{ Health Literacy } & \multicolumn{2}{l|}{ SDM } \\
\cline { 2 - 5 } & $\mathbf{r}$ & $\mathbf{p}$ & $\mathbf{r}$ & $\mathbf{p}$ \\
\hline Age & -0.321 & $<0.001^{* * *}$ & 0.036 & 0.693 \\
Education level & 0.480 & $<0.001^{* * *}$ & 0.093 & 0.313 \\
Habits of reading & 0.030 & 0.745 & -0.039 & 0.673 \\
newspapers (frequency) & & & & \\
Source of health & 0.320 & $<0.001^{* * *}$ & 0.130 & 0.156 \\
knowledge (type) & & & 0.258 & $0.004^{* *}$ \\
Health literacy & - & - & 0
\end{tabular}

Notes: $* * \mathrm{P}<0.01, * * * \mathrm{P}<0.001$.

\section{Causal Relationship Between HL And The Patient With Cancer's Feeling Of The Extent In SDM}

The results of the path analysis mode shown in Figure 1 show the direct effect of HL for SDM and indirect effect of Edu on SDM.
There is a significant difference between the HL outpatient dialogue (Standardized Beta $=0.63$ ) and the $\mathrm{HL}$ drug Information (Standardized Beta $=0.77$ ) and HL.

For demographic variables, significant difference was found between HL and the educational level (Standardized Beta $=0.61)$, while there was a statistically significant difference between the HL score and the SDM score (Standardized Beta $=0.25)$ as well.

Table 9 shows that direct effect of HL on SDM is 0.25 and indirect effect of education level on SDM through HL is $0.1025(0.61 \times 0.25)$; the overall effect is $0.4025(0.25+$ $0.61 \times 0.25)$.

\section{Discussion}

\section{Influencing Factors Related To HL And SDM In Patients With Cancer}

The theoretical path model proposed by Edwards et al ${ }^{13}$ has shown that through more knowledge development, HL can improve self-management and participation in decision-making, making the patients informed and the information

Table 7 Important Factors Predicting Health Literacy Of Patient With Cancers (Multiple Linear Regression) (N=120)

\begin{tabular}{|c|c|c|c|c|c|c|}
\hline Independent Variable & $\begin{array}{l}\text { Original Regression } \\
\text { Coefficient }\end{array}$ & $\begin{array}{l}\text { Std. } \\
\text { Error }\end{array}$ & $\begin{array}{l}\text { Standardized Regression } \\
\text { Coefficient }\end{array}$ & t-Value & P-Value & $\begin{array}{l}95 \% \text { Confidence } \\
\text { Interval }\end{array}$ \\
\hline Constant (intercept) & 8.032 & 0.625 & & 12.842 & $<0.00 I^{* * * *}$ & $6.793 \sim 9.27 \mid$ \\
\hline Age & -0.369 & 0.187 & 0.177 & -1.973 & 0.051 & $-0.739 \sim 0.002$ \\
\hline Gender $^{\mathrm{a}}$ & 0.514 & 0.270 & 0.154 & 1.902 & 0.060 & $-0.021 \sim 1.050$ \\
\hline Education level & 0.623 & 0.166 & 0.341 & 3.746 & $<0.001 * * *$ & $0.293 \sim 0.952$ \\
\hline $\begin{array}{l}\text { Habit of reading newspaper } \\
\text { (frequency) }\end{array}$ & 0.009 & 0.183 & 0.004 & 0.051 & 0.959 & $-0.353 \sim 0.372$ \\
\hline $\begin{array}{l}\text { Source of health knowledge } \\
\text { (type) }\end{array}$ & 0.307 & 0.130 & 0.210 & 2.362 & $0.020^{*}$ & $0.050 \sim 0.565$ \\
\hline
\end{tabular}

Notes: In this regression model, $R=0.566, R^{2}=0.320$, Adjusted $R^{2}=0.291, F$ value $=10.748,{ }^{*} p<0.05, * * * p<0.001$. ${ }^{2}$ The reference group is male.

Table 8 Important Predictors Affecting The Extent Of SDM In Patients With Cancer (Multiple Linear Regression) N=120

\begin{tabular}{|c|c|c|c|c|c|c|}
\hline Independent Variable & $\begin{array}{l}\text { Original Regression } \\
\text { Coefficient (B) }\end{array}$ & $\begin{array}{l}\text { Std. } \\
\text { Error }\end{array}$ & $\begin{array}{l}\text { Standardized Regression } \\
\text { Coefficient }(\beta)\end{array}$ & t-Value & P-Value & $\begin{array}{l}\text { 95\% Confidence } \\
\text { Interval }\end{array}$ \\
\hline Constant (intercept) & 3.112 & 0.521 & & 5.978 & $<0.001 * * *$ & $2.081 \sim 4.143$ \\
\hline Age & 0.084 & 0.101 & 0.088 & 0.827 & 0.410 & $-0.117 \sim 0.284$ \\
\hline Gender $^{\mathrm{a}}$ & -0.051 & 0.146 & -0.033 & -0.347 & 0.729 & $-0.340 \sim 0.239$ \\
\hline Education level & -0.017 & 0.094 & -0.022 & -0.179 & 0.858 & $-0.202 \sim 0.169$ \\
\hline $\begin{array}{l}\text { Habits of reading } \\
\text { newspaper (frequency) }\end{array}$ & -0.094 & 0.097 & -0.096 & -0.961 & 0.339 & $-0.287 \sim 0.099$ \\
\hline $\begin{array}{l}\text { Source of health } \\
\text { knowledge (type) }\end{array}$ & 0.050 & 0.071 & 0.076 & 0.713 & 0.478 & $-0.090 \sim 0.191$ \\
\hline Health literacy & 0.128 & 0.050 & $0.28 I$ & 2.573 & $0.011 *$ & $0.030 \sim 0.227$ \\
\hline
\end{tabular}

Notes: In this regression model, $\mathrm{R}=0.287, \mathrm{R}^{2}=0.082$, Adjusted $\mathrm{R}^{2}=0.034, \mathrm{~F}$ value $=1.690, P$ value $=0.130$. ${ }^{\mathrm{a}}$ The reference group is male. $* \mathrm{P}<0.05, * * * \mathrm{P}<0.00 \mathrm{I}$. 


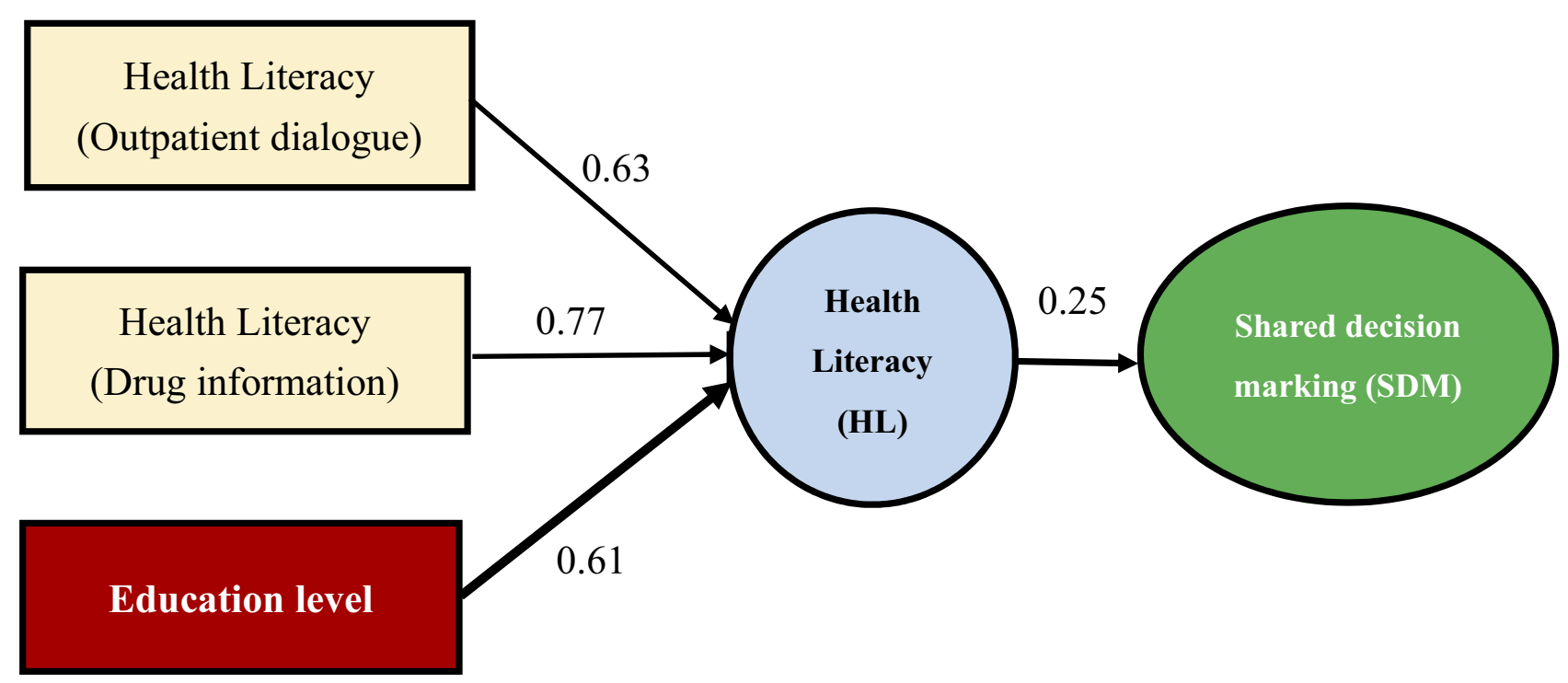

Figure I Path analysis of health literacy $(\mathrm{HL})$ and shared decision making (SDM).

shared. In the United States, a survey of 1841 adults newly diagnosed lung cancer, breast cancer, colorectal cancer, or prostate cancer revealed that $\mathrm{HL}$ is positively correlated with the patient's Health-Related Quality of Life (HRQOL), which support the clinical practice that health care of patient with cancer should take HL into consideration. ${ }^{14} \mathrm{HL}$ has an impact on treatment compliance, ${ }^{15}$ participants can build up their health knowledge by reading patient decision aids (PDAs), apply their HL skills, demonstrate health behaviors, and look for advice from health professionals to make sure their choices and participate in decision-making. ${ }^{16}$ It is increasingly recognized that patient's HL plays a key role in affecting doctor-patient communication and health outcomes. ${ }^{17}$ The above researches are in accordance with the finding in this study that the HL and SDM are statistically significantly correlated.

In this study, we found that the HL and SDM are significantly correlated, how to improve the patient's HL, such that they can understand scientific evidence and capable of making decisions, is the goal of each medical personnel. Therefore, providing the patients with the

Table 9 Causal Relationship Between Health Literacy (HL) And Shared Decision Making (SDM)

\begin{tabular}{|l|l|l|l|l|}
\hline $\begin{array}{l}\text { Latent } \\
\text { Independent } \\
\text { Variable }\end{array}$ & $\begin{array}{l}\text { Latent } \\
\text { Dependent } \\
\text { Variable }\end{array}$ & $\begin{array}{l}\text { Direct } \\
\text { Effect }\end{array}$ & $\begin{array}{l}\text { Indirect } \\
\text { Effect }\end{array}$ & $\begin{array}{l}\text { Total } \\
\text { Effect }\end{array}$ \\
\hline $\begin{array}{l}\text { Health literacy } \\
\text { Education level } \\
\text { Education level }\end{array}$ & SDM & $\begin{array}{l}0.25 \\
0\end{array}$ & $\begin{array}{l}0.61 \times 0.25 \\
0\end{array}$ & 0.4025 \\
\hline
\end{tabular}

related information, improving their knowledge, and encouraging them to participate in decision-making should be implemented in various medication and treatment options, such that real SDM can be achieved.

\section{Important Predictors Affecting HL And SDM In Patients With Cancer}

The predictive factor affecting the HL in patients with cancer is the educational level, and the important predictor for SDM is HL. Foreign studies have also found that the level of HL is more predictive of health condition than education, income, ethnicity, or other sociodemographic variables. ${ }^{18}$ Another study also identified education as an important independent predictor of HL. ${ }^{19}$ A survey of 509 patients with rheumatoid arthritis (RA) for HL and trust in physicians and SDM found that patients with limited HL influenced SDM and their health outcomes. ${ }^{20}$

\section{The Causal Relationship Between The HL Of Patient With Cancers And The Feeling Of The Extent Of SDM}

A cross-sectional study of 511 patient with breast cancers in breast surgery wards in three teaching hospitals in northern Taiwan, using the European Health Literacy Survey Questionnaire (HLS-EU-Q) and 9-item SDM Questionnaire (SDM-Q-9), revealed that average SDM-Q-9 score was $80.5 \%$. Among the 7 possible determinants of HL, only individual factors (i.e., age, education level, cancer stage, and duration) were important factors to affect HL, and education level actively predicted HL. Both SDM and 
self-assessed health status were significantly affected by HL. The results showed that demographic variables (age, education, cancer stage, and duration) significantly predicted HL, while HL significantly affected SDM and self-assessment of health status; in terms of the consequences of HL, the results show that HL can influence patients with breast cancer to participate in decision-making. ${ }^{21}$ When the medical consultation can be carried out in an "interactive" way, through "teaching" or "role play", the physician can make sure that the patient has understood the content and starting a dialogue in this mode can successfully open the channel for doctorpatient communication, provide the patient greater flexibility, and facilitate more active participation in the decision-making process.

\section{Conclusion}

As the advance in medical biotechnology and the year-by-year rise in incidence of cancer domestically, the treatment options for patient with cancers become more and more diverse and complex, making it a difficult decision. We show in this study that patients' ability to participate in medical decision-making is significantly related to their HL, which in turn is significantly related to education. Therefore, to reach a satisfactory SDM, medical professionals should understand the HL of the patient in the disease group when preparing the Patient Decision Aid (PDA). After that, a PDA matching the patient's HL allows the patient to understand scientific evidence and data from evidence-based medicine, and finally make decisions according to their preferences and values.

Medical field is highly specialized, and patients are indeed easily facing difficulty in making treatment decisions. Therefore, medical institutions should aim to achieve patient HL, so that patients have relevant health awareness, knowledge, and capability, thereby enhance patient participation in decision-making, reach real SDM, and promote positive doctor-patient communication.

The results in the study indicated that the level of education directly affects HL; therefore, in the future, disease-related health education should be provided for patients with lower education level to achieve their HL. HL directly affected the SDM, so it is necessary to help patients achieve their HL that SDM can be improved.

\section{Ethics Approval And Consent To Participate}

The study was approved by the IRB of National Taiwan University Hospital Hsinchu Branch (106-076-E). This study was conducted in accordance with the Declaration of Helsinki.

\section{Acknowledgments}

We appreciate the funding (107-HCH072) from National Taiwan University Hospital Hsinchu Branch, and the statistical consulting assistance provided by the Biotechnology Research and Development Center. We also thank Professor Meixiu Lu, Professor Xuanyi Huang, Professor Shuyuan Liang and Associate Professor Meilan Ke for their guidance and recommendations in the research process. We are even more grateful to all patient with cancers who participated in this study.

\section{Disclosure}

The authors report no conflicts of interest in this work.

\section{References}

1. Laws \& Regulations Database of The Republic of China (January 6 of 2016). Patient Autonomy Act. Available from: http://law.moj.gov. tw/Index.aspx. Accessed October 11, 2019.

2. Lu M-S. Medical and Nursing Ethics. Taipei: Wu Nan; 2018.

3. Ministry of Health and Welfare: taiwan Patient Safety Net -questionnaire Survey of 2015. Available from: http://www.patientsafety. mohw.gov.tw/Content/Messagess/list.aspx?SiteID=1\&MmmID= 621273300443065506. Accessed October 11, 2019.

4. Joint Commission of Taiwan (June 21 of 2017). The Effectiveness Assessment Survey of Shared Decision Making in 2016. Available from: http://www.tjcha.org.tw/FrontStage/index.aspx. Accessed October 11, 2019.

5. Liao H-H. Brief introduction of share decision making. Cheng Vhing Med J. 2017;13(2):4-8.

6. Elwyn G, Laitner S, Coulter A, Walker E, Watson P, Thomson R. Implementing shared decision making in the NHS. BMJ. 2010;341: c5146. doi:10.1136/bmj.c5146

7. Davey HM, Davey E, Houssami N, et al. Medical tests. Health Expectations. 2002;5(4):330-340. doi:10.1046/j.1369-6513.2002.00 194.x

8. Charles C, Gafnv A, Whelan T. Shared decision-making in the medical encounter. Soc Sci Med. 1997;44(5):681-692. doi:10.1016/ S0277-9536(96)00221-3

9. Ballesteros J, Moral E, Brieva L, Ruiz-Beato E, Prefasi D, Maurino J. Psychometric properties of the SDM-Q-9 questionnaire for shared decision-making in multiple sclerosis: item response theory modelling and confirmatory factor analysis. Health Qual Life Outcomes. 2017;15(1):79. doi:10.1186/s12955-017-0656-2

10. Légaré F, Kearing S, Clay K, et al. Are you SURE: assessing patient decisional conflict with a 4-item screening test. Can Family Phys. 2010;56:e308-e314.

11. Couet N, Desroches S, Robitaille H, et al. Assessments of the extent to which health-care providers involve patients in decision making: a systematic review of studies using the OPTION instrument. Health Expect. 2015;18(4):542-561. doi:10.1111/ hex. 12054

12. Kriston L, Scholl I, Holzel L, Simon D, Loh A, Harter M. The 9item shared decision making questionnaire (SDM-Q-9). Development and psychometric properties in a primary care sample. Patient Educ Couns. 2010;80(1):94-99. doi:10.1016/j.pec.20 09.09.034

13. Edwards M, Wood F, Davies M, Edwards A. The development of health literacy in patients with a long-term health condition: the health literacy pathway model. BMC Public Health. 2012;12 (1):130. doi:10.1186/1471-2458-12-130 
14. Halverson JL, Martinez-Donate AP, Palta M, et al. Health literacy and health-related quality of life among a population-based sample of patient with cancers. J Health Commun. 2015;20(11):1320-1329. doi:10.1080/10810730.2015.1018638

15. Megwalu UC. Health literacy in patients with head and neck cancer: an understudied issue. JAMA Otolaryngol Head Neck Surg. 2017;143 (7):645-646. doi:10.1001/jamaoto.2017.0242

16. Smith SK, Nutbeam D, McCaffery KJ. Insights into the concept and measurement of health literacy from a study of shared decisionmaking in a low literacy population. J Health Psychol. 2013;18 (8):1011-1022. doi:10.1177/1359105312468192

17. Williams MV, Davis T, Parker RM, Weiss BD. The role of health literacy in patient-physician communication. Fam Med. 2002;34 (5):383-389.
18. Weiss BD, Mays MZ, Martz W, et al. Quick assessment of literacy in primary care: the newest vital sign. Ann Family Med. 2005;3(6):514522. doi:10.1370/afm.405

19. Kalichman SC, Ramachandran B, Catz S. Adherence to combination antiretroviral therapies in HIV patients of low health literacy. J Gen Intern Med. 1999;14(5):267-273. doi:10.1046/j.1525-1497.1999.00334.x

20. Barton JL, Trupin L, Tonner C, et al. English language proficiency, health literacy, and trust in physician are associated with shared decision making in rheumatoid arthritis. J Rheumatol. 2014;41 (7):1-8. doi:10.3899/jrheum.131350

21. Hou WH, Huang YJ, Lee Y, Chen CT, Lin GH, Hsieh CL. Validation of the integrated model of health literacy in patients with breast cancer. Cancer Nurs. 2017. doi:10.1097/NCC.0000000000000540
Patient Preference and Adherence

\section{Publish your work in this journal}

Patient Preference and Adherence is an international, peer-reviewed, open access journal that focusing on the growing importance of patient preference and adherence throughout the therapeutic continuum. Patient satisfaction, acceptability, quality of life, compliance, persistence and their role in developing new therapeutic modalities and compounds to optimize clinical outcomes for existing disease

\section{Dovepress}

states are major areas of interest for the journal. This journal has been accepted for indexing on PubMed Central. The manuscript management system is completely online and includes a very quick and fair peer-review system, which is all easy to use. Visit http:// www.dovepress.com/testimonials.php to read real quotes from published authors. 